\title{
Nigerian Financial Sector and Manufacturing Industries
}

\author{
Ogunsakin, Sanya (Ph.D) \\ Department Of Economics, Faculty Of The Social Sciences, University Of Ado-Ekiti, P.M.B. 5363, Ado-Ekiti, \\ Ekiti State, Nigeria.
}

\begin{abstract}
In this study, we conducted an empirical investigation of the impact of financial sector reforms on the performance of manufacturing sector in Nigeria. The data series employed were gathered from various sources such as the Central Bank of Nigeria statistical bulletin, Economic and Financial Review, monthly and annual report and statement of account for various years.

The study also employed the multivariate co-integration method by Johansen (1988) and Jeselius (1990). The time series property of quarterly data employed were first investigated. This is then followed by testing for cointegrated variables. Based on the time series property of data used, the results clearly indicated that there was one co-integrating vector. Findings from the study showed that financial sector reforms in Nigeria did not have significant impact on the growth of manufacturing out-put in Nigeria during study period. Based on these findings, it is recommended that appropriate policies that will increase credit to the private sector and ensure efficient allocation of credit to the private sector are required. Also, Central Bank of Nigeria should be more effective in the area of supervision of commercial banks in loan disbursement to manufacturers
\end{abstract}

\section{Introduction}

One significant element of any market driven economy is the quality of its institutions. These institutions play advisory and facilitatory roles in the industrialization process. This concesus results from a wide body of evidence suggesting that a country's overall economic performance is affected by its institutions. It has been observed that ailing institutions are associated with slower growth, lower total factor productivity and lower per capital income (Mauro, 1995 Hall and James 1999, and Acemoglu et. Al. 2001) as cited by Mojeed (2009). Also, underdeveloped money and capital markets are not only distort economic growth but also affect the performance of manufacturing industries. Typically, industries rely on various sources for obtaining funds for investment. These sources are broadly classified into debt and equity. While debt refers to the resources generated by loans from the financial institutions and through the issuance of various debt whereas equity refers essentially to financing through stock markets and various forms of investment, by effectively reducing the cost of borrowing and making it easier for the industries to raise capital from the equity market.

Moreover, the financial institutions in Nigeria are highly liquid to make industrial loans, but they believe that lending to the manufacturing sector is not justified in terms of risks and costs (Olorunsola, 2001). The perceived high risk comes from a number of sources ranging from difficulty in obtaining information on a firm's true financial condition and performance, inadequacies in the legal environment including long delay in adjudicating cases of debtor delinquency and problems with contract enforcement. Consequently, banks charge high interest rate, demand high level of collateral and make few loans of more than a year in term. In addition to the above high interest rate in Nigerian Financial System is a reflection of the extremely poor infrastructural facilities and inefficient institutional framework necessary to bring about substantial reduction in the risk associated with financing an extremely traumatized economy (Ogwuoma, 1980).

Furthermore, the remainder of this paper is organized as follows. In the next section, we provide a brief review of the financial sector reforms in Nigeria and also impact of financial sector reforms on manufacturing industries in Nigeria, in section III we set out an empirical model to estimate the impact of financial sector reforms on manufacturing industries in Nigeria. A discussion of data and relevant variable construction is provided in this section. Following this, in the fifth section where we discuss the estimation strategy along with the results. A brief conclusion is provided in the sixth section.

\section{Financial Sector Reforms In Nigeria}

Prior to SAP, aside from indigenization policy which gave government 60 per cent stake in otherwise foreign banks that operated in the country, there was no limit to the capital base requirements for banks. However, following the adoption of SAP, a limit of N1.0 billion was prescribed for commercial banks and about N500 million for merchant banks. This was however increased subsequently to N2 billion prior to Soludo. In Soludo's era, the commercial banks were mandated to recapitalize from a minimum capital base of N2 billion to $\mathrm{N} 25$ billion. As a corollary to asset base requirements, both prudential and monetary policy guidelines were prescribed for the banking sector. In pre-SAP era, banks operated in an environment of credit allocation, 
interest rate subsidy, fixed exchange rate and foreign exchange rationing. This however gave way to liberalization post-SAP era.

An assessment of the outcome of the reforms over time is shown in Table 1. As can be deduced from the figure, post-SAP era witnessed rapid expansion in number and branches networks of banks, from 40 and 1323 commercial/merchant banks in 1985 to 120 and 2382 in 1993 . During the Post-Reform lethargy era, some of the banks became distressed and were liquidated, reducing their number to 89 and 2220 branch networks in 1998. Although the Soludo reforms consolidated the banks through mergers, acquisitions and new issues to 25 banks, their total branch networks increased to about 4500 in 2006 (Soludo 2007).

Table I: Basic indicators of banking sector performance pre-SAP, $1^{\text {st }} 2^{\text {nd }}, 3^{\text {rd }}$ and $4^{\text {th }}$ phases

\begin{tabular}{|c|c|c|c|c|c|c|c|c|c|c|c|c|c|}
\hline \multirow{2}{*}{$\begin{array}{l}\text { Period } \\
\text { Item }\end{array}$} & \multicolumn{3}{|c|}{ Pre - SAP } & \multicolumn{3}{|c|}{ Post - SAP } & \multicolumn{3}{|c|}{ Performs Emery } & \multicolumn{3}{|c|}{ Pre- Soludo } & \multirow{2}{*}{$\begin{array}{l}\text { Solud } \\
\text { o } \\
2006\end{array}$} \\
\hline & 1970 & 1980 & 1985 & $\begin{array}{l}198 \\
6\end{array}$ & 1990 & 1993 & 1994 & 1997 & 1998 & 2000 & 2002 & 2004 & \\
\hline No of Banks & 15 & 26 & 40 & 41 & 107 & 120 & 116 & 115 & 89 & 89 & 89 & 89 & 25 \\
\hline $\begin{array}{l}\text { No. of Bank } \\
\text { Branches }\end{array}$ & 273 & 752 & 1323 & $\begin{array}{l}139 \\
4\end{array}$ & 2013 & 2382 & 2547 & 2477 & 2220 & 2306 & 3123 & 3382 & 4500 \\
\hline $\begin{array}{lr}\text { Total } & \text { Assets } \\
\text { Based } & \text { of } \\
\text { Banks } & \text { (N } \\
\text { Billion) } & \end{array}$ & 1.2 & 17.3 & 37.0 & 48.1 & 117.4 & $\begin{array}{l}341 . \\
7\end{array}$ & $\begin{array}{l}357 . \\
5\end{array}$ & $\begin{array}{l}681 . \\
7\end{array}$ & $\begin{array}{l}818 . \\
4\end{array}$ & $\begin{array}{l}1707 \\
.0\end{array}$ & $\begin{array}{l}2766 \\
.6\end{array}$ & $\begin{array}{l}2309 . \\
0\end{array}$ & $\begin{array}{l}6555 . \\
0\end{array}$ \\
\hline $\begin{array}{lr}\text { Total } & \text { Assets } \\
\text { Bases } & \text { of } \\
\text { Bank } & (\$ \\
\text { Billion }) & \\
\end{array}$ & 1.6 & 32.1 & 37.0 & 14.5 & 13.0 & 15.6 & 16.2 & 31.1 & 37.4 & 15.6 & 21.9 & 24.2 & 51.1 \\
\hline $\begin{array}{lr}\text { Capital } & \text { and } \\
\text { Reserves } & \text { (N } \\
\text { Billion) } & \\
\end{array}$ & 0.1 & 0.4 & 1.1 & 1.5 & 5.2 & 10.9 & 9.1 & 35.2 & 72.9 & $\begin{array}{l}394 . \\
6\end{array}$ & $\begin{array}{l}821 . \\
9\end{array}$ & $\begin{array}{l}1050 . \\
0\end{array}$ & 957.0 \\
\hline $\begin{array}{lr}\text { Av. Cap } & \text { and } \\
\text { Reserves } & \text { per } \\
\text { Bank } & \text { (N } \\
\text { Billion) } & \end{array}$ & $\begin{array}{l}0.00 \\
39\end{array}$ & $\begin{array}{l}0.01 \\
60\end{array}$ & $\begin{array}{l}0.02 \\
82\end{array}$ & $\begin{array}{l}0.03 \\
64\end{array}$ & $\begin{array}{l}0.048 \\
4\end{array}$ & $\begin{array}{l}0.09 \\
06\end{array}$ & $\begin{array}{l}0.09 \\
06\end{array}$ & $\begin{array}{l}0.30 \\
59\end{array}$ & $\begin{array}{l}0.81 \\
86\end{array}$ & $\begin{array}{l}4.43 \\
35\end{array}$ & $\begin{array}{l}9234 \\
8\end{array}$ & $\begin{array}{l}11,79 \\
78\end{array}$ & $\begin{array}{l}38.28 \\
00\end{array}$ \\
\hline $\begin{array}{l}\text { Liquidity } \\
\text { Ratio }\end{array}$ & 94.5 & 47.6 & 65.0 & 36.4 & 44.3 & 42.2 & 48.5 & 40.2 & 46.8 & 58.0 & 48.8 & 41.5 & 52.9 \\
\hline $\begin{array}{l}\text { Cash } \\
\text { Reverser } \\
\text { Ratios }\end{array}$ & 5.2 & 10.6 & 1.8 & 1.7 & 2.9 & 6.0 & 5.7 & 7.8 & 8.3 & 10.0 & 11.6 & 5.9 & 6.1 \\
\hline $\begin{array}{l}\text { Loan - to - } \\
\text { Deposit Ratio }\end{array}$ & 51.3 & 66.7 & 66.9 & 83.2 & 66.5 & 42.9 & 60.9 & 76.6 & 74.4 & 46.2 & 78.4 & 85.4 & 97.5 \\
\hline & & & & & $\mathrm{Me}$ & randus & items & & & & & & \\
\hline $\begin{array}{l}\text { Exchange } \\
\text { rate }\end{array}$ & $\begin{array}{l}07.1 \\
00\end{array}$ & $\begin{array}{l}0.54 \\
00\end{array}$ & $\begin{array}{l}1.000 \\
0\end{array}$ & $\begin{array}{l}3.32 \\
00 \\
\end{array}$ & $\begin{array}{l}9,000 \\
0\end{array}$ & $\begin{array}{l}21,8 \\
800\end{array}$ & $\begin{array}{l}22.0 \\
000\end{array}$ & $\begin{array}{l}21,8 \\
900 \\
\end{array}$ & $\begin{array}{l}21,8 \\
900\end{array}$ & $\begin{array}{l}109, \\
5500\end{array}$ & $\begin{array}{l}126, \\
4000\end{array}$ & $\begin{array}{l}132,3 \\
500\end{array}$ & $\begin{array}{l}128,2 \\
000\end{array}$ \\
\hline
\end{tabular}

Signs of institutional weakness were apparent through out the period under review. In pre-SAP era, average asset base per bank declined from N1.2 billion in 1980 to N0.924 billion in 1985. Thereafter, there was apparent growth in Naira terms post-SAP era as the average was above the recommended N2 billion marks. However, following devaluations of exchange rates, these figures were the equivalent of US $\$ 0.122$ billion in 1993 to US $\$ 0.272$ billion in 2004 . These figures tended to suggest $s$ that Nigerian banks were too weak to compete globally.

Although a number of analyst have often argued that this outcome could be the result of assets undervaluation in the face of exchange rate depreciation, a number of the banks were adversely affected especially those saddled with external debt service burdens. The institutional ratios attested to this. In pre-SAP era, both the liquidity and cash reserve ratios deteriorated and the situation persisted in post-SAP era as they were quite below the prescribed minimum by the monetary authorities.

With regard to credit purvey, the banking sector exhibited mixed performance. The immediate postSAP witnessed increased attention given by the banking sector to the production sectors. The share of agricultural and manufacturing sectors in banking sector credit increased post-SAP and the production sector as a whole accounted for an annual average of 58.3 per cent of total to the economy (see Table 2). However, during the era of reforms lethargy, miscellaneous lending crowded out production credit, to the extent that even in post-Soludo era, it accounted for about 70.6 per cent of total credit. While it can be argued that post Soludo's reforms may have helped to build and foster a competitive and healthy financial system, it is 
debatable if the structure of their portfolio investments has the capacity to support the desired economic development aspiration of the proponents. This could be inferred from Table 2 which shows that despite the rapid increase in lending to the economy, the share of production sectors of the economy especially manufacturing and mining sectors remained low and indeed declined proportionately over time suggesting that the new monies may have been channeled into miscellaneous activities.

Table II: Sectoral Distribution of Commercial Banks Loans

\begin{tabular}{|l|l|l|l|l|l|l|l|l|l|}
\hline Sector & $\begin{array}{l}\text { Av. Ann. } \\
\text { Total }\end{array}$ & Agric & Man. & Mining & RE\&C & Product & Miscel & Svs others & Total \\
\hline Period & N'Million & \% share & \% share & \% share & \% share & \% share & \% share & \% share & \% share \\
\hline $\begin{array}{l}\text { Pre SAP } \\
1970-79\end{array}$ & $3,952.9$ & 2.3 & 12.5 & 0.9 & 8.9 & 24.7 & 1.8 & 73.5 & 100.00 \\
\hline $\begin{array}{l}\text { Pre-_SAP } \\
1980-85\end{array}$ & $11,978.3$ & 7.2 & 23.7 & 1.0 & 17.1 & 49.0 & 4.7 & 46.3 & 100.00 \\
\hline $\begin{array}{l}\text { Post - SAP } \\
1986-93\end{array}$ & $32,053.4$ & 14.7 & 31.0 & 1.6 & 11.0 & 58.3 & 5.0 & 36.6 & 100.00 \\
\hline $\begin{array}{l}\text { Refms Leth } \\
1994-1998\end{array}$ & $202,177.9$ & 13.0 & 34.7 & 8.7 & 0.0 & 54.7 & 34.6 & 10.6 & 100.00 \\
\hline $\begin{array}{l}\text { Pre } \\
\text { Soludo } \\
1999-2004\end{array}$ & $3,248,367.7$ & 6.1 & 25.0 & 8.3 & 0.0 & 39.4 & 57.2 & 3.4 & 100.00 \\
\hline $\begin{array}{l}\text { Soludo } \\
\text { 2004 }\end{array}$ & $5,686,669.2$ & 4.6 & 23.0 & 9.1 & 0.0 & 36.7 & 39.4 & 2.2 & 100.00 \\
\hline $\begin{array}{l}\text { Post Soludo } \\
\text { 2005 }\end{array}$ & $7,392,670.0$ & 3.8 & 19.9 & 9.1 & 0.0 & 32.8 & 36.7 & 1.7 & 100.00 \\
\hline $\begin{array}{l}\text { Post Soludo } \\
\text { 2006 }\end{array}$ & $9,684,397.7$ & 3.2 & 16.9 & 8.0 & 0.0 & 28.1 & 28.1 & 1.3 & 100.00 \\
\hline Source: Computer From CBN Statistical Bulletin & & & & & & \\
\hline
\end{tabular}

\section{Financial Reforms And Manufacturing Industries}

Upon the assumption of duty in 2004 as the governor of Central bank of Nigeria, Professor Charles Soludo indicated that the commercial banks should recapitalize from a minimum capital base of \#2 billion to \#25 billion. As at the period, 89 banks were in operation made up of about 5 to 10 banks whose capital base were already above the \#25 billion marks, another group of 11 to 30 banks within the \#10 to \#20 billion marks, while the remaining 50 to 60 banks were quite below the \#10 billion marks. A period of about 12 month was given to these banks to recapitalize through new issues, mergers and acquisitions. Failure to do so would mean the liquidation of such banks by the monetary authority. Appropriate legislative backing was obtained for this, and at the end of the exercise, about 25 banks emerged. A total of 18 banks failed to meet the recapitalization criteria and had their licenses revoked.

Ostensibly, the series of reforms in the banking and financial sector were geared towards positioning banks and other financial institutions to play their primary and very crucial role of financial intermediation in the economy as the driving force for generating high saving and investment. With the adoption of the financial institutional reforms in Nigeria, the assumption is that banking sector liberalization accompanied by increased capital base requirement is a necessary condition for improved performance of the banking especially in the area of financing the manufacturing sector. This was echoed by the proponents of the initial banking sector reforms in SAP era and re-echoed by the pre and post Soludo era. The underlying argument draws its strength from the neo-classical supply side economics, rooted in Say's law that "supply creates its own demand" (Jhingan, 2003). That is increased capital base may imply increased availability of loan able funds to the Nigerian manufacturing sector.

On the contrary, none of the aforementioned financial institutional reforms have been able to deal specifically with low manufacturing performance and output in the economy. In Nigeria, the role of institutional reform in development of the Nigeria manufacturing sector has not been fully addressed and the impact has not been fully felt. Manufacturing sector in Nigeria has been experiencing a stunted growth and its contribution to gross domestic product (GDP) has remained low. For instance, the manufacturing as a whole remains small, accounting for only 6.6 percent of GDP in 2000 and 12 percent of employment (World Bank, 2002). The production indices, using 1990 as the base year also indicated that while agriculture and services experienced modest growth from 103.5 and 101.5 and 297.0 between 1991 and 1999 respectively, manufacturing sector recorded a decline from 109.4 to 92.3 in the same period. It is also sad to mention that capacity utilization in the manufacturing sector declined from about 70.1 percent in 1980 to just 44.3 percent in 2002 (CBN, 2002).

In addition, lack of access to finance has been the major problem facing the Nigerian manufacturing sectors. Lack of funds has made it difficult for the Nigerian industries to make investment in modern machines, information technology and human resources development which are critical in reducing production costs, raising productivity and improving competitiveness. Low investment has been traced largely to banks 
unwillingness to make credits available to manufacturers, owing partly to this mis-match between the short-term nature of banks funds and the medium to long-term nature of funds needed by Nigerian industries. In addition, banks perceive manufacturing as a high risk venture, such as commerce, in which the returns are also very high. Even when credit is available, high lending rates, which is over 40 percent at a time, makes it unattractive to the manufacturers.

Moreover, since the introduction of SAP, high and increasing cost of production has been recorded by most Nigerian firms as a major constraint on their operations. Increased cost, traced largely to high interest and exchange rates, has resulted into increase unit price of manufacturers, low effective demand for goods liquidity squeeze and fallen capacity utilization rates. The special purpose fund created to provide "cheap and long-term" finance for industries by Nigerian Economic Reconstruction fund (NERFUND) in the late 1980's was crippled as a result of fluctuations in the exchange rate. Firms who borrowed funds had a liability, twice and in some cases thrice the original amount (Adebiyi, 2004).

Another constraint that hinders the performance of Nigerian manufacturing sectors, most especially in the area of financing their operations, is the government's fiscal operation. The largest single spender in the economy is government who often finance its deficit through the ways and means of Central Bank of Nigeria $(\mathrm{CBN})$. This mode of deficit financing directly increase the monetary base and increase the level of excess liquidity with adverse effect on exchange rate and price level (Ojo, 2001). Looking at the financial deficits through the money market, one can adduce some negative impact on the banking industry and the Nigerian economy. The way it affects banking industry and the Nigerian economy is that once the government gets the money from Treasury Bills (TB), through mopping the liquidity in the system, it deprives the private sector from having loanable funds. This, in turn makes the cost of the fund very high for manufacturing firms.

\section{Empirical Survey}

There are three ways of measuring the performance of manufacturing sector. These include manufacturing production growth rate, employment in the manufacturing sector, capacity value-added. However, in this paper, emphasis would be based on the first measure which is manufacturing growth rate share.

Following the theoretical propositions of IS-LM model, for the successful assessment of the impact of financial sector reforms on the performance of manufacturing sector, with reference to the works developed by Mundell, (1963) and Fleming, (1963) and revised by Tobin and Macelo, (1980) as cited by Mojeed, (2010), the model used in this paper is explicity specified as follows.

LMPGR= F (LM2GDP, RTR, LINV, LFDI, LTDC, INF, U)

$\mathrm{LMPGR}=\log$ of manufacturing production growth rate

$\mathrm{LM} 2 \mathrm{GDP}=\log$ of ratio of Broad Money to GDP

$\mathrm{RTR}=$ Real Interest Rate

LINV $=$ Log of investment

LFDI $=$ Log of foreign Direct Investment

LTDC $=\log$ of total Domestic Credit

$\mathrm{INF}=$ Inflation Rate

The coefficient in the model are in elasticities, since the variables are in logarithm form and as a result measure direct response of manufacturing production growth rate to unit changes in the explanatory variables. Data for the study spanned 1980-2009 and were obtained from the CBN Statistical Bulletin and Annual Report, various issues.

V. Results And Major Findings

Table III: Unit Root Test (With Intercept)

\begin{tabular}{|l|l|l|l|l|}
\hline Variables & ADF Test & Phillips Perron Test \\
\hline & Level & $\mathbf{1}^{\text {st }}$ Difference & Level & $\mathbf{1}^{\text {st }}$ Difference \\
\hline LMPGR & -1.18311 & $-10,96169$ & -1.172351 & $-10,934900$ \\
\hline LM2GDP & -1.947536 & -3805375 & -1.827476 & -10.32108 \\
\hline RTR & -2.37562 & -8.624115 & -2.231673 & -8.713125 \\
\hline LINV & -7.767457 & -5.3656931 & -7.943051 & -29.56163 \\
\hline LFDI & -2.829707 & -6.519105 & -2.479322 & -6.486242 \\
\hline LTDC & -0.516364 & -9.03212347 & -0.686661 & -9.476343 \\
\hline INF & -1.846436 & -1.62634 & -0.94678 & \\
\hline
\end{tabular}

Results from the ADF, PP tests show in Table III reveals that the variable are not stationary in levels except inflation but became stationary when converted to first differences. These stationary findings are then used to formulate our cointegration tests. Since the level of the variables exhibit unit roots, our-task is to check whether these variables in levels shares one or more unit roots in which case they may be considered cointegrated. 


\section{Co-Integration Test}

Since the level of variables exhibit unit roots, our task is to check whether these variables share one or more unit roots in which case the may be considered cointegrated.

\section{Cointegration And Error Correction Model}

Table Iv: Residual Stationary Test For Mpgr

\begin{tabular}{|l|l|l|ll|}
\hline VARAIBLE & ORDER OF INTEGRATION & ADF VALUE & $\begin{array}{l}\text { CRITICAL VALUE FOR } \\
\text { 95\% ADF }\end{array}$ & FD \\
\hline ECM & $1(0)$ & -2.8423 & -2.8645 & \\
\hline
\end{tabular}

From the result in table iv above, the value of the observed ADF statistics for the residuals in greater than its critical value. Therefore, it is stationary. This shows there is no unit root in the residuals from the model it implies the variables in the model are cointegrated.

Table V: Parsimonious Error Correction Model For Mpgr

\begin{tabular}{|l|l|l|l|}
\hline VARIABLES & COEFFICIENT & STANDARD ERROR & T-VALUE/PROBABILITY \\
\hline CONSTANT & 1.26611 & 2.1676 & 0.816848 \\
\hline$\partial$ LM2(-1) & -0.066991 & 0.9564 & 0.96001 \\
\hline$\partial$ GDP(-1) & -0.064222 & 0.15219 & 2.1013 \\
\hline$\partial$ RIR $(-1)$ & 0.27420 & -0.99854 & 1.0350 \\
\hline$\partial$ LINV & 2.5371 & 2.1611 & 0.36024 \\
\hline$\partial$ LFDI & 0.12365 & 0.13716 & 1.9483 \\
\hline$\partial$ LTD & 0.67381 & 0.44746 & 2.8402 \\
\hline$\partial$ INF & -0.17057 & 0.39945 & -1.0737 \\
\hline ECM & -0.66770 & 0.24128 & -2.1418 \\
\hline
\end{tabular}

R-Squared $=0.44$

Durbin-Watson Stat. $=1.986$

F-Stat $(9.23)=1.933 / 0.098$

Having established the existence of co-integration, we now model changes in the manufacturing output as response to departure from ordinary linear combination or the 1(1) variables augmented by shortrun dynamics from the current and lagged first differences of the variables included in the co-integrating vector.

The negative coefficient of the error correction term ECM (t-1) is significant assuring that the cointegrating relationship between the variables is valid. Essentially, it implies that when an exogeneous shock disturbs the equilibrium condition $66.79 \%$ of its effect is adjusted in one period. The short-run impact of explanatory variables on manufacturing production growth rate is positive, but the coefficient is much smaller than that found in the long-run model.

\section{Concluding Remarks}

The paper reviewed impact of financial reforms on the performance of manufacturing sector of Nigerian economy between 1980-2009. From the study, the financial sector in Nigeria has witnessed significant growth since the adoption of structural adjustment program (SAP) with potential to contribute to the growth of manufacturing sector of Nigerian Economy. However, the liberalization of the Nigerian Financial institutions has not completely changes the modus operandi of the operators who are still largely risk averter. Indeed empirical evidence from the study suggests that despite the recent reforms in the sector, it still made less contribution to the growth of manufacturing sector of Nigerian Economy. The sector is still faced with several challenges. However, appropriate policies that will increase credit to the private sector and ensure efficient allocation of credit to the private sector are required. This is in addition of evolving policies to positively change banks ledging behavior and preferences as well as curtailing government interferences in the sector through crowding out effects.

In conclusion, he financial sector reforms remain important components of Nigerian economy, as it plays a crucial role in the forces of financial intermediation when public confidence in the sector is sufficiently in place.

\section{References}

[1]. Adewuyi, A.O (2002), "Balance of payments constraints and Growth Rate Differences Under Alternative Policy Regime in Nigeria", Monogragh Series No. 10.

[2]. Acemoglu, D.S. Johnson and J.A. Robinson "the colonial origins of comparative development: An empirical investigation. American Economic Review Vol. 91 No. 5, pp. 1369, 1401, 2001.

[3]. Anderson J.E. "Trade and informal Institutions" in Handbook of International Trade: Economic and Legal Analysis of Laws and Institutions, E.K. Choi and J.C. Hartigan (eds). Oxford, Basil Blackwell, pp. 279-293, 2005. 
[4]. Balogun, E.D. "Credit Policies and Industrial development in Nigeria". CBN Economic and Financial Review (1991), 29(2): pp. 138-155.

[5]. Beck, T.G. Clarke, A. Groff, P. Keefer and P. Walsh (2002). New tools and New test in comparative political Economy. The Database of political Institutions and Regulation and Competition policy, Development Research Group, World Bank, Washington, D.C.

[6]. Bekaert, G.,H and Lundblad, C. "Does Financial Liberalization Spur Growth” NBER Working Paper Series No. 8245, April, 2001.

[7]. Bhatia, R. and Khatkhate, D. "Financial Intermediation, Savings Mobilization and Entrepreneurial Development: The African Experience”, IMF Staff Papers, Vol. 22, No.1, March, 1975, pp. 132-158.

[8]. Central Bank of Nigeria (2000): Statitical Bulletin, p.27.

[9]. Central Bank of Nigeria (2000): Annual Report and Statement of Accounts, p. 47.

[10]. Diaku, (1972): A capital-surplus Illusion: The Nigerian Case Revisited. The Nigerian Economic Society, 135-145.

[11]. Enders, W. (1995): Applied Econometric Time Series, New York, John Wiley Engle R.F. and Granger C.W.J. (1987): Cointegration and Error Correction Representations, Estimation and Testing" Econometrical, March, pp. 251-276.

[12]. Eyraud, L. (2002): "Globalization and Inequalities", A contribution to the G20 2002 Workshop.Falola, Toyin (1998): Corruption in the Public Service 1954-1960 corruption and the Crisis of Institutional Reforms in Africa, Lewiston; Edwin Mellen Press, 1998.

[13]. Granger, C.W. (1969): Investigating Casual Relations by Econometric Models and Cross-Spectral Methods. Econometrical, Vol. 37.

[14]. Granger, CW.J. and Newbold, P. (1977):'The Time Series Approach to Econometric Model Buildings" in New Methods in Business Cycle Research: Proceeding from a conference, edited by C.A. sins, Federal Reserve Bank of Minneapolis.

[15]. Greene, W.H. (1997): Econometric Analysis, Third Edition, New York, Macmillan.

[16]. Gurajati, D.M (1995): Basic Econometrics, Third Edition, New York, McGraw-Hill.

[17]. Johannes Jutting (2003),"Institutions and Development: A Critical Review" Technical Papal No. 201 produced as part of the research programme on social Institutions and Dialogue.

[18]. Kates, Steven (1998): Say's Law and the Keynesian Revolution: How Macroeconomic Theory Lost its way. Edward Elgard Publishing Limited. ISBN 978-1-85898-748-4. 